\title{
LANDSLIDE HAZARD ZONATION IN AND AROUND KEDARNATH REGION AND ITS VALIDATION BASED ON REAL TIME KEDARNATH DISASTER USING GEOSPATIAL TECHNIQUES
}

\author{
Divya Uniyal $^{1, *}$, Saurabh Purohit ${ }^{2}$, Sourabh Dangwal $^{1}$, Ashok Aswal ${ }^{1}$, M.P.S.Bisht ${ }^{1}$, M.M.Kimothi ${ }^{3}$ \\ ${ }^{1}$ Uttarakhand Space Application Centre, Dehradun, India - divya.uniyal@rediffmail.com \\ ${ }^{2}$ Indian Institute of Remote Sensing, Dehradun \\ ${ }^{3}$ MNCFC, New Delhi
}

Commission V, SS: Disaster Monitoring, Damage Assessment and Risk Reduction

KEYWORDS: Landslide Hazard Zonation, GIS, Orthorectification, Drainage Density, Geomorphology

\begin{abstract}
:
Landslides are one of the frequently happening disasters in this hilly state of Uttarakhand which accounts to the loss of lives and property every year especially during the rainy season which lead to affect the families. With the development of satellite observation technique, advanced data analysis tool and new modeling techniques landslide hazard zonation map can be prepared.

In the present study, Landslide Hazard Zonation (LHZ) for Kedarnath to Augustmuni region of Rudraprayag district of Uttarakhand state was carried out using Remote Sensing and GIS technique. For the preparation of LHZ map, year 2010 high resolution satellite data have been used. After preprocessing of the data various thematic layers are prepared in GIS environment. The weighted-rating system technique were used for the LHZ map showing the five zones, namely "very low hazard", "low hazard", "moderate hazard", "high hazard" and "very high hazard" . This map has been validated after the tragedy of Kedarnath in Uttarakhand, Total no. of 224 Landslides has been marked from Kedarnath to Augustmuni region just after the kedarnath tragedy in year 2013. When this landslides thematic layer is overlaid on LHZ, the study shows that approximately $50 \%$ landslides was there where in LHZ map high and very high hazard zones have been identified. After the tragedy our team workers have gone to the field, with the help of DGPS around 40 ground control points have been taken to validate our result. So by using this geospatial technique around $50 \%$ people's life can be saved.
\end{abstract}

\section{INTRODUCTION}

A "landslide" is the movement of a mass of rock, debris, or earth down a slope, under the influence of gravity (Nemčok et al., 1972; Varnes, 1978; Hutchinson, 1988; Cruden, 1991; Cruden and Varnes, 1996).Different factors can initiate mass movement such as intense and prolonged rainfall, earthquake shocks, rapid snow melt and anthropogenic factors such as unplanned excavations for construction of building, roads, canal and mining. Predicting hazardous events like landslides are particularly difficult because it is an instantaneous event with lot of background processes going on. The range of landslide phenomena is extremely large, making mass movements one of the most diversified and complex natural hazard to model and simulate.

\footnotetext{
${ }^{*}$ Corresponding author
}

Occurrence of landslides is prevalent in geodynamic sensitive belts i.e. zones and areas repeatedly rocked by earthquakes and affected by other neotectonic activities (Bolt et. al., 1975). Hill slopes in the Himalaya are known for their instability due to sensitive geodynamics. Combination of inherent, external and orogenic factors has made this terrain highly vulnerable to landslides. It is one of the most frequently happening disasters in the hilly state of Uttarakhand which accounts to the precious loss of lives and property every year especially during the rainy season.

Landslide hazard is considered under the natural hazard category, which is defined as the probability of occurrence within a specified period of time and within a given area of potentially damaging phenomenon (Varnes 1984). A landslide hazard zonation (LHZ) map is prepared in advance to facilitate mitigation strategies in the wake of any landslide hazard (Anbalagan et al. 2015). Here the area is classified into different LHZ ranging from very low hazard zone to very high hazard zone (Arora et. al,. 2004). It provides a prior knowledge of landslide 
probable zones on the basis of a set of geo-environmental factors suitable for landslides locally.

Remote sensing along with GIS provides great advantages in LHZ mapping. Remote sensing images are helpful in factor characterization and landslide inventory mapping. Temporal capability of remote sensing imageries are of a great help in acquiring past and present landslide incidences locally which further has a great significance in LHZ . Terrain information, such as, land cover, geology, geomorphology and drainage could also be derived from it and existing thematic information can be updated to enable the quantification of human interference on the earth's surface (Rai et al.2014). GIS is very effective in data handling, manipulation and statistical measures. With its excellent spatial data processing and multitasking capacity, has attracted sincere attention in natural disaster assessment.

For the preparation of Landslide Hazard Zonation (LHZ) map, year 2010 high resolution satellite data have been used. After preprocessing of the data various thematic layers are prepared in GIS environment such as Proximity to fault, Lithology, Slope, Geomorphology, Density of lineament, Drainage density, Intersection of lineament, Land use/Land cover, Soil depth, Soil texture, Slope, Aspects, rainfall map, Road map and geology. The weighted-rating system technique based on the relative importance of various factors as derived from remotely sensed data and other thematic maps were used for the landslide hazard zonation map. The different classes of thematic layers were assigned the corresponding rating value as attribute information in the GIS and a map was generated for each data layer. Each class within a thematic layer was assigned a rating from 1 to 9 . Summing up of these attribute maps were then multiplied by the corresponding weights to yield the Landslide Hazard Index (LHI) for each pixel. Weighted-rating values have been re-adjusted. Using the above said techniques A LHZ map was prepared showing the five zones, namely "very low hazard", "low hazard", "moderate hazard", "high hazard" and "very high hazard" which can be critical for warning and preparedness and mitigation measures in advance. This map have been validated after the tragedy of Kedarnath in Uttarakhand, all landslides have been marked from Kedarnath to Augustmuni. CARTOSAT-2 and LISS-IV data of the year june, 2013 have been used. Orthorectification of CARTOSAT-2 and LISS-IV data have been done in ERDAS IMAGINE-LPS, after this thematic layer of landslides have been prepared in ARC GIS software. Total no. of 224 Landslides has been marked from Kedarnath to Augustmuni region just after the kedarnath tragedy in year 2013 in Uttarakhand state. When this landslides thematic layer is overlaid on LHZ, the study shows that approximately $50 \%$ landslides was there where in LHZ map high and very high hazard zones have been identified. After the tragedy our team workers have gone to the field for the verification, with the help of (Differential Global Positioning System) DGPS around 40 ground control points have been taken to validate our result. So by using this geospatial technique around 50\% people's life can be saved. Mitigation of disasters due to landslides can be successful only with detailed knowledge about the expected frequency, character and magnitude of mass movements in an area. Landslide hazard zonation can identify susceptible areas prone to landslides and effective policies can be made beforehand to at least minimize the damage caused by them. Remote Sensing and GIS tools can be very handy due to their peculiar advantages.

\section{OBJECTIVES}

The major objectives of the study are as follows:

- To develop thematic layers i.e. Drainage map, Soil map (Texture, Depth and Drainage), contour map, digital elevation model, slope angle map, land use/land cover map, thrust (buffer) map, geology.

- To prepare Landslide Hazard Zonation Map.

- To prepare landslide map on 2013 satellite data, after Kedarnath Disaster.

- Validation of Landslide Hazard zonation map which was made in 2010

\section{STUDY AREA}

The Kedarnath town is a nagar panchayat in Rudraprayag district is located in the western extremity of the Central Himalaya in the Mandakini River valley. River is originated from the Chorabari Glacier (3895 m a.s.1.) and joins Saraswati River (which originates from Companion glacier) near Shri Kedarnath temple passing through Rambara, Gaurikund and Sonprayag where Vashuki Ganga merges with it, finally becoming the part of Alaknanda River at Rudraprayag (640 m asl). The Shri Kedarnath town is situated on the outwash plane of the Chorabari and Companion glaciers (WIHG, 2013). The most remote of the four Dham sites, Kedarnath is located in the Himalayas, about $3,583 \mathrm{~m}(11,755 \mathrm{ft})$ above sea level near Chorabari Glacier, the head of river Mandakini, and is flanked by snow-capped peaks. The nearest road head is at Gaurikund.

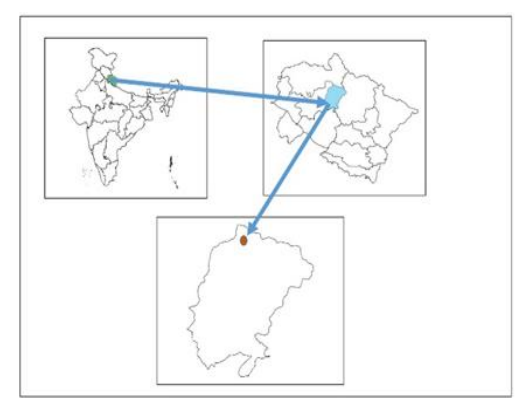

Figure 1. Study Area

\section{DATA USED}

\subsection{Satellite data}

LISS-3 data, LISS-4 data

\subsection{Thematic layers}


Drainage map, Soil map (Texture, Depth and Drainage), contour map, digital elevation model, slope angle map, land use/land cover map, thrust (buffer) map, geology.

\section{METHODOLOGY}

The methodology is as follows:

5.1. For the preparation of Landslide Hazard Zonation (LHZ) map:

For the year 2010 high resolution satellite data (orthorectified merged product of CARTOSAT-2 and LISS-IV data in ERDAS IMAGINE-LPS Software) have been used.

$>$ After preprocessing of the data various thematic layers are prepared in GIS environment such as Proximity to fault, Lithology, Slope, Geomorphology, Density of lineament, Drainage density, Intersection of lineament, Land use/Land cover, Soil depth, Soil texture, Slope, Aspects, rainfall map, Road map and geology.

$>$ The weighted-rating system technique based on the relative importance of various factors as derived from remotely sensed data and other thematic maps were used for the landslide hazard zonation map.

$>$ The different classes of thematic layers were assigned the corresponding rating value as attribute information in the GIS and a map was generated for each data layer. Each class within a thematic layer was assigned a rating from 1 to 9. Summing up of these attribute maps were then multiplied by the corresponding weights to yield the Landslide Hazard Index (LHI) for each pixel. Weighted-rating values have been re-adjusted. Using the above said techniques A LHZ map was prepared showing the five zones, namely "very low hazard", "low hazard", "moderate hazard", "high hazard" and "very high hazard".

5.2 For the generation of thematic layer of landslide after kedarnath tragedy:

$>$ Orthorectification of CARTOSAT-2 and LISS-IV data have been done in ERDAS IMAGINE-LPS, after this thematic layer of landslides have been prepared in ARC GIS software.

$>$ All landslides have been marked from Kedarnath to Augustmuni by using CARTOSAT-2 and LISS-IV data of the duration june, 2013 have been used.

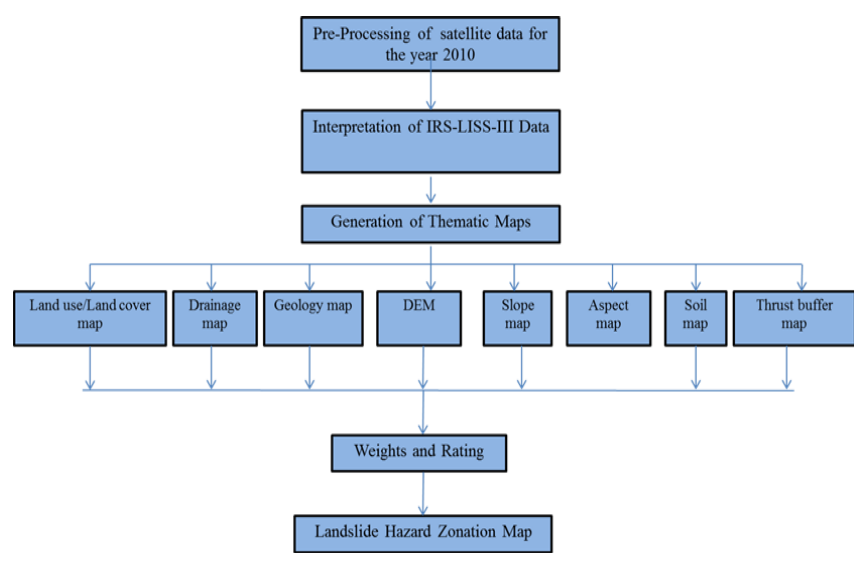

Figure 2. Methodology for preparation of Landslide Hazard Zonation map

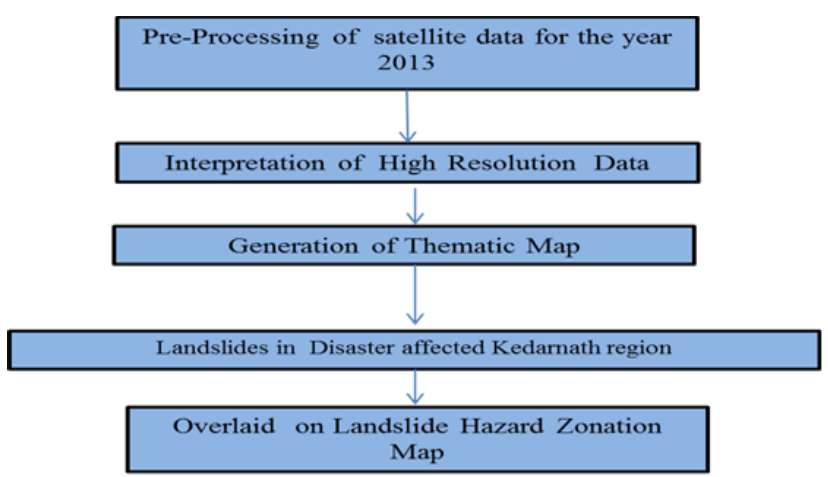

Figure 3. Methodology for Validation of Landslide Hazard Zonation map

\section{OUTCOMES \& RESULT}

In first part, Thematic layers have been development i.e. Drainage map, Soil map (Texture, Depth and Drainage), contour map, digital elevation model, slope angle map, land use/land cover map, thrust (buffer) map, and geology etc. based on these thematic layers Landslide Hazard Zonation Map have been prepared. In second part by taking satellite data of the year 2013 thematic layer of landslides have been marked. Thematic layer of landslides which have been marked on satellite data overlaid on Landslide Hazard Zonation Map of study area.

In brief, Outcomes of the study are as follows:

- Development of thematic layers i.e. Drainage map, Soil map (Texture, Depth and Drainage), contour map, digital elevation model, slope angle map, land use/land cover map, thrust (buffer) map, and geology. 
- Preparation of Landslide Hazard Zonation Map.

- Preparation of landslide map on 2013 satellite data, after Kedarnath Disaster.

- Validation of Landslide Hazard zonation map which was made in 2010 .

6.2 Result shows that Total 224 landslides which have been marked on satellite data just after kedarnath disaster when we have overlaid this thematic layer on Landslide Hazard Zonation Map of study area (which have been made earlier) then we have observed that approximately $50 \%$ marked landslides are lying in high and very high priority landslide zone so we can say that we got $50 \%$ good results. Losses through landslides can be prevented, if relief measures have been taken out by the higher authority by considering accuracy and effectiveness of this Landslide hazard zonation map which have been prepared with the help of remote sensing and GIS.

\begin{tabular}{|l|r|l|r|}
\hline $\begin{array}{l}\text { Route from } \\
\text { Kedarnath } \\
\text { to } \\
\text { Augustmuni }\end{array}$ & $\begin{array}{l}\text { Total } \\
\text { landslides }\end{array}$ & $\begin{array}{l}\text { Marked } \\
\text { landslides lying } \\
\text { in Very high } \\
\text { and High } \\
\text { priority } \\
\text { landslide zone }\end{array}$ & $\begin{array}{l}\text { Percentage } \\
(\%)\end{array}$ \\
\hline $\begin{array}{l}\text { Kedarnath to } \\
\text { Sonprayag }\end{array}$ & 88 & & 53.4 \\
\hline $\begin{array}{l}\text { Sonprayag to } \\
\text { Okhimath }\end{array}$ & 76 & & 59.21 \\
\hline $\begin{array}{l}\text { Okhimath to } \\
\text { Augustmuni }\end{array}$ & 60 & 45 & 53.33 \\
\hline
\end{tabular}

\begin{tabular}{|l|l|l|l|}
\hline & & $\begin{array}{l}\text { Marked } \\
\text { landslides } \\
\text { lying in } \\
\text { Very } \\
\text { high and }\end{array}$ & \\
& & $\begin{array}{l}\text { High } \\
\text { priority } \\
\text { landslide } \\
\text { zone }\end{array}$ & $\begin{array}{l}\text { Percentage } \\
(\%)\end{array}$ \\
\hline $\begin{array}{l}\text { Overall route } \\
\text { Kedarnath to }\end{array}$ & $\begin{array}{l}\text { Total } \\
\text { landslides }\end{array}$ & & \\
\hline
\end{tabular}

Table 1. Validation of Landslide Hazard Zonation map

\section{CONCLUSION}

Landslide hazard zonation maps are of huge importance in hilly areas to assess the potentiality of landslide occurrence. This is one of the key aspects of the disaster management plan of any hill state. Mitigation of disasters due to landslides can be successful only with detailed knowledge about the expected frequency, character and magnitude of mass movements in an area. Landslide hazard zonation can identify susceptible areas prone to landslides and effective policies can be made beforehand to at least minimize the damage caused by them. Remote Sensing and GIS tools can be very handy due to their peculiar advantages.

In hilly state such like Uttarakhand, LHZ map should be prepared for all hilly region. In those maps, High and very high hazard zone should be highlighted and this information should be reached to the democrats and to the govt. so effective measures can be taken and lives of the people can be saved which is most precious and valuable thing all around us.

\section{Field Pictures collected by our team members:}

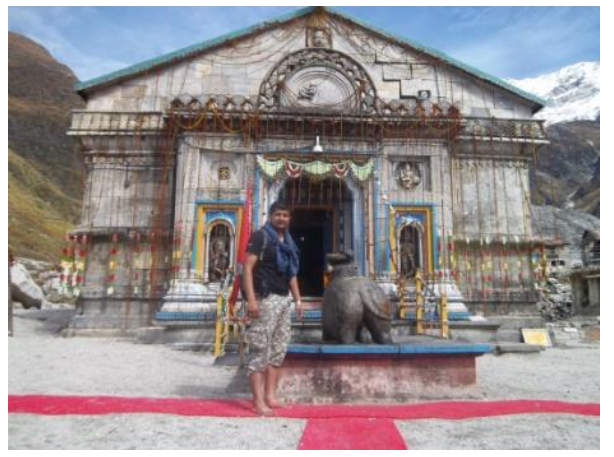

Figure 4. Kedarnath temple

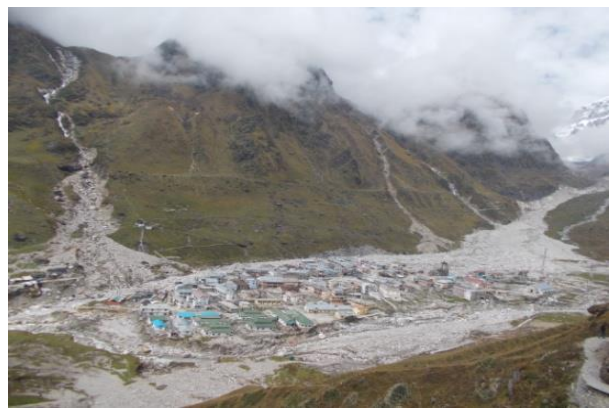

Figure 5. Aerial photo of 20th June, 2013

\section{REFERENCES}

Anbalagan, R., Kumar, R., Lakshmanan, K., Parida, S. and Neethu, S, 2015., Landslide hazard zonation mapping using frequency ratio and fuzzy logic approach, a case study of Lachung valley Sikkim, Geoenvironmental Disasters ,2:6 1-17.

Arora, M.K., Das Gupta, A.S., Gupta, R.P. 2004, An artificial neural network approach for landslide hazard zonation in the Bhagirathi (Ganga) Valley, Himalayas. International Journal of Remote Sensing, 25(3),559-572.

Bolt, B.A., Landslide Hazard, Geological Hazard, Springer Verlog, New York, 1975, 150.

Cruden, D.M., 1991, A simple definition of a landslide. Bulletin International Association of Engineering Geology ,43, 27-29. 
Cruden, D.M. and Varnes, D.J., 1996, Landslide types and processes. Landslides, Investigation and Mitigation, Transportation Research Board Special Report 247, Washington D.C, 36-75.

Hutchinson, 1988, J.N., Morphological and geotechnical parameters of landslides in relation to geology and hydrology. Proceedings 5th International Symposium on Landslides, Lausanne, 1: 3-35.

Nemčok, A., Pašek, J. and Rybář, J., 1972, Classification of landslides and other mass movements. Rock Mechanics, 4, 71-78.
Rai, Praveen Kumar., Mohan, Kshitij and Kumra, V.K. (2014). Landslide Hazard and its Mapping using Remote Sensing and GIS. Journal of Scientific Research Vol. 58, 1-13.

Varnes, D.J., 1978, Slope movements: types and processes. Landslide analysis and control, National Academy of Sciences, Transportation Research Board Special Report 176, Washington, 11-33.

Varnes, D.J., 1984, Landslide Hazard Zonation: a review of principles and practice; UNESCO. Nat Hazards , 3:61

WIHG., Report on Kedarnath devastation, 2013, 1-66.Wadia Institute of Himalayan Geology December, 2013. 